\title{
Genome-wide discovery and characterization of microsatellite markers from Melipona fasciculata (Hymenoptera: Apidae), cross-amplification and a snapshot assessment of the genetic diversity in two stingless bee populations
}

\author{
Geice Ribeiro da Silva ${ }^{1, *}$, Isis Gomes de Brito SOUZA, ${ }^{2, *}$ fabia de Mello PEREIRA³, Bruno de Almeida SOUZA ${ }^{3}$, \\ Maria Teresa do Rego LOPES ${ }^{3}$, Paul BenTZeN $^{4}$ and Fabio Mendonça DINIZ ${ }^{3,5, * *}$ \\ 1 Universidade Federal do Piauí, Campus Universitário Ministro Petrônio Portella, Ininga, Teresina, PI, 64049-550, Brazil; \\ e-mail: geiceamb_bio@yahoo.com.br \\ 2 Universidade Federal do Piauí, Northeast Biotechnology Network - RENORBIO, Teresina, PI, 64049-550, Brazil; \\ e-mail: isisgomesmd@hotmail.com \\ ${ }^{3}$ EMBRAPA Meio-Norte, Laboratory of Molecular Biology \& Biotechnology, CP: 01, CEP: 64006-220, Teresina, PI, Brazil; \\ e-mail: bruno.souza@embrapa.br, fabia.pereira@embrapa.br, maria-teresa.lopes@embrapa.br \\ ${ }^{4}$ Department of Biology, Dalhousie University, Halifax, NS, B3H 4J1, Canada; e-mail: paul.bentzen@dal.ca \\ ${ }^{5}$ EMBRAPA Caprinos e Ovinos, Caixa Postal: 145, CEP: 62010-970, Sobral, CE, Brazil; e-mail: fabio.diniz@embrapa.br
}

Key words. Hymenoptera, Apidae, Meliponini, Melipona fasciculata, molecular markers, microsatellites, population differentiation, population structure, Brazil

\begin{abstract}
Brazilian native meliponines are currently threatened by increased human impacts. The assessment of their genetic variation by microsatellite DNA markers can assist in the conservation of populations and help in the planning and establishment of efficient management strategies. The purpose of this study was to develop the first set of microsatellite markers for Melipona fasciculata, selected from partial genome assembly of Illumina paired-end reads. Primer pairs were designed for each detected locus at their flanking regions. Bee samples were genotyped from two different populations of Northeastern Brazil for marker characterization and validation. A total of 17 microsatellite loci displayed polymorphism. Mean $H_{E}$ and $H_{O}$ heterozygosities were 0.453 and 0.536 , respectively. $P I C$ across all loci ranged from 0.108 to 0.714 . A genetic diversity analysis revealed high values for population differentiation estimates $\left(F_{S T}=0.194, R_{S T}=0.230\right.$, and $\left.D_{\text {est }}=0.162\right)$ within the investigated region. PCoA and Bayesian clustering showed a separation of the species into two distinct clusters. These microsatellite markers have demonstrated strong potential for population-level genetic studies. Moreover, the preliminary analysis of the genetic diversity in $M$. fasciculata provides provisional evidence of significant population differentiation between the two studied populations.
\end{abstract}

\section{INTRODUCTION}

Stingless bees (Hymenoptera: Apidae: Meliponini) are a diverse group of bees regarded for their great economic and ecological importance. For instance, beekeeping provides a sustainable source of income under a low-cost investment for smallholder farming communities, and these native bees provide an efficient pollination service in both natural and agricultural systems (Garibaldi et al., 2013).

Currently, native meliponines are threatened by increased human impacts such as destruction of native vegetation and consequent landscape transformation, and indiscriminate use of pesticides for agriculture (Winfree et al., 2009; Potts et al., 2010; Silva et al., 2015). Anthropogenic disturbances or intervention may negatively affect the existence of small populations of native stingless bees, leading to the risk of local extinction (Klein et al., 2007; Silva et al., 2014). Therefore, a clear understanding of the genetic variation and population structure of meliponine bees can contribute to the development of effective conservation strategies to secure the continued survival of these original populations and the species itself.

The Melipona (Melikerria) fasciculata Smith, 1854 (Hymenoptera: Apidae), popularly known as "uruçu-cinzenta" or "tiúba", is a native stingless bee species that can be found in the neotropical region of Brazil, within the states of Pará, Tocantins, Maranhão, Piauí and Mato Grosso (Silveira et al., 2002). Apart from its role as a pollinator in most ecosystems and crops (NunesSilva et al., 2013), a great interest in the species has emerged because (i) stingless beekeeping is relatively easy, as long as

\footnotetext{
* These authors contributed equally to this work.

** Corresponding author; e-mail: fabio.diniz@embrapa.br
} 
flowering plants are available, and (ii) its production of honey and geopropolis with antioxidant potential (Dutra et al., 2014) and anti-inflammatory effect (Liberio et al., 2011). The species has also an important place in a rapidly growing market with wide possibilities for economic exploitation, mainly by family farmers (Holanda et al., 2012; Venturieri et al., 2012; Alves, 2013; Gostinski, 2018). As such, beekeepers have been continuously trying to improve honey production by nest transportation and trading among themselves (Kerr et al., 1996; Jaffé et al., 2015). In fact, this unregulated and uncontrolled practice of transporting and trading colonies from one region to another affects the genetic structure of stingless bee populations by altering factors such as geographic distance between populations or physical barriers to gene flow (Nogueira et al., 2014; Byatt et al., 2016; Jaffé et al., 2016).

Microsatellites, stretches of short DNA sequences tandemly repeated, have become the markers of choice for high-resolution assessment of genetic variation and population structure studies, most importantly, due to their abundance throughout the eukaryote genome and their hypervariability (Goldstein \& Schlötterer, 1999). Emerging technologies in DNA sequencing (i.e. next generation sequencing - NGS) have proven to be useful for identifying microsatellite loci from the large amounts of sequence data they generate with much less effort and low cost, therefore, challenging traditional approaches for their development (Zalapa et al., 2012; Souza et al., 2015). Microsatellite markers developed for a studied species can also be transferred among related species, of the same genus or different genera in the same family, which considerably reduces their development costs and shortens development times in a non-source species (Selkoe \& Toonen, 2006).

In this paper, we describe the first set of microsatellite markers developed for Melipona fasciculata, selected from partial genome assembly of Illumina paired-end reads, and test the crossamplification of all microsatellite loci in four non-source species. A preliminary analysis of its genetic variation within a relatively short geographical range is also performed to characterize and validate these polymorphic markers.

\section{MATERIALS AND METHODS}

\section{Bee materials and genomic DNA isolation}

Genomic DNA from Melipona fasciculata was extracted from each adult worker thorax $(\mathrm{n}=50)$ using the Wizard Genomic DNA Purification Kit (Promega, Madison, WI, USA) according to the manufacturer's instruction. Bees were collected from hives originally from the Northeast region of Brazil, in the states of Piauí (Elesbão Veloso city; $6^{\circ} 11^{\prime} 56.2^{\prime \prime} \mathrm{S}$ and $42^{\circ} 11^{\prime} 43.8^{\prime \prime} \mathrm{W}$ ) and Maranhão (São Bento city; $2^{\circ} 42^{\prime} 30.6^{\prime \prime} \mathrm{S}$ and $44^{\circ} 50^{\prime} 18.9^{\prime \prime} \mathrm{W}$ ). DNA was also isolated from four additional species, $M$. marginata, M. subnitida, Nannotrigona testaceicornis and Frieseomelitta varia (Table 1) for cross-species amplification testing. Three worker bee samples from each species were collected from hives located at Embrapa Meio-Norte in Teresina, Piauí $\left(5^{\circ} 02^{\prime} 22.8^{\prime \prime} \mathrm{S}\right.$ and $\left.42^{\circ} 48^{\prime} 12.9^{\prime \prime} \mathrm{W}\right)$. The extracted DNA samples were electrophoresed on $0.8 \%$ agarose gel to test for overall quantity and quality of the DNA yield.

\section{Library preparation and next generation sequencing}

A single individual with the highest quality DNA yield was selected for sequencing. DNA was quantified using a PicoGreen protocol and was run using a Perkin Elmer Fusion DNA Quantifier (Perkin Elmer, Waltham, MA, USA). An Illumina paired-end library was created using $1 \mathrm{ng}$ of genomic DNA, following the standard protocol of the Illumina Nextera XT Library Prepara- tion kit (Illumina, San Diego, CA, USA). DNA was tagged and fragmented by the Nextera XT transposome, followed by limitedcycle PCR amplification, AMPure XP magnetic-bead purification (Agencourt Bioscience Corporation, Beverly, MA, USA) and the Illumina Nextera XT bead-based normalization protocol. The DNA library was sequenced using a MiSeq Benchtop Sequencer (Illumina). Contigs were created from the resulting paired-end sequence data (reads) using CLC Genomics Workbench 7.0.4 (Qiagen, Carlsbad, CA, USA).

\section{SSR loci search and primer design}

All these contigs were subsequently added directly into Msatcommander 0.8.2 (Faircloth, 2008) for detection of possible microsatellite loci with at least four repeats, except for dinucleotides (six repeats), and designing of primer pairs for each detected locus at their flanking regions. Long mononucleotide repeats were ignored for marker development. Primer design was performed with the Primer3 (Rozen \& Skaletsky, 2000).

\section{SSR-PCR amplification for primer validation and genotyping}

Genomic DNA from five individuals, each from different colonies, were initially used to validate all designed primer pairs using polymerase chain reactions (PCRs). Reactions were performed in a $10-\mu \mathrm{L}$ total volume containing at least $10 \mathrm{ng}$ of genomic DNA, with 1.25 to $1.5 \times$ buffer, 2 to $2.5 \mathrm{mM} \mathrm{MgCl}_{2}, 10 \mathrm{mM}$ dNTP mix, $0.25 \mathrm{mM}$ of each primer and 0.25 units of Taq DNA polymerase (Thermo Fisher Scientific, Waltham, MA, USA) or HotStar Taq DNA Polymerase (Qiagen). All amplifications were run in a Veriti 96-well Thermal Cycler (Applied Biosystems, Foster City, CA, USA) using the PCR temperature profile indicated in Table 1. We also tested the cross-species amplification success of these loci with three samples from each of four additional species, Melipona marginata, M. subnitida, Nannotrigona testaceicornis, and Frieseomelitta varia, as the DNA extraction described above. All amplification products, from source and non-source bee species, were screened by silver nitrate detection on denatured $6 \%$ polyacrylamide gels. Subsequently, additional M. fasciculata samples were genotyped from two different locations, Piauí (20 inds) and Maranhão (20 inds), each from different colonies, to obtain baseline allele frequency information.

\section{Data analysis}

The genotyped data were initially analyzed using Microchecker ver. 2.2.3 (van Oosterhout et al., 2004) to test for the presence of null alleles, large allele dropout and scoring errors by stuttering. Observed and expected heterozygosities $\left(H_{O}\right.$ and $\left.\mathrm{H}_{E}\right)$, the number of alleles $(\mathrm{Na})$, and the polymorphic information content $(P I C)$ were determined using Cervus ver. 3.0 (Kalinowski et al., 2007). Allelic richness $\left(A_{R}\right)$ as a measure of the number of alleles per locus independent of sample size was calculated by Fstat ver. 2.9.3.2 (Goudet, 1995). Deviations from Hardy-Weinberg equilibrium $(H W E)$ and tests for linkage disequilibrium were conducted using Genepop software (Raymond \& Rousset, 1995). The Bonferroni correction was applied when multiple pairwise tests were performed to assess the significance $(P<0.05)$.

The genetic diversity for each locus was evaluated by Arlequin ver. 3.5 (Excoffier \& Lischer, 2010), which determined the value of $\theta\left(F_{S T}\right)$ for the whole sample set.

A Bayesian grouping admixture model was used to infer possible population structuring using the software Structure ver. 2.3.3 (Pritchard et al., 2000). The program was set up for 1,000,000 Markov chain Monte Carlo repetitions after an initial burn-in of 500,000 steps. The estimate of the best $K$ was calculated based on five replications for each $K$ (from 1 to 6 ) using Structure harvester ver. 0.6.92 (Earl \& vonHoldt, 2012). The program Clumpp 
Table 1. Characteristics and cross-species amplification of 18 microsatellite markers developed for Melipona fasciculata.

\begin{tabular}{|c|c|c|c|c|c|c|c|c|c|c|c|}
\hline Locus & Primer sequence $\left(5^{\prime}-3^{\prime}\right)$ & $\begin{array}{l}\text { Motifs } \\
\text { repeats }\end{array}$ & $\begin{array}{c}\mathrm{Ta} \\
\left({ }^{\circ} \mathrm{C}\right)\end{array}$ & $\mathrm{Na}$ & $\begin{array}{l}\text { Size range } \\
\quad(\mathrm{bp})\end{array}$ & $\begin{array}{l}\text { Reaction } \\
\text { profile }\end{array}$ & $\begin{array}{l}\text { Melipona } \\
\text { marginata }\end{array}$ & $\begin{array}{l}\text { Melipona } \\
\text { subnitida }\end{array}$ & $\begin{array}{l}\text { Nannotrigona } \\
\text { testaceicornis }\end{array}$ & $\begin{array}{c}\text { Frieseomelitta } \\
\text { varia }\end{array}$ & $\begin{array}{l}\text { GenBank } \\
\text { access. no. }\end{array}$ \\
\hline Mfsc3 & $\begin{array}{l}\text { F: GAGCGAGAGGGAGCAAGATA } \\
\text { R: TAGTAACGTAATTCTGCGCGAT }\end{array}$ & $(\text { AGAT })_{14}$ & 50 & 2 & 090-094 & $\mathrm{PCR}_{\text {STD }}$ & + & - & - & + & KT730150 \\
\hline Mfsc7 & $\begin{array}{l}\text { F: TCTACCCATCTCTGTTTCTCTCC } \\
\text { R: TCGCAGTTTCGTTGATTTTG }\end{array}$ & $(\text { ATCT })_{10}$ & 50 & 2 & $232-236$ & $\mathrm{PCR}_{\mathrm{STD}}$ & - & - & - & - & KT730151 \\
\hline Mfsc10 & $\begin{array}{l}\text { F: AGTAGAACGATTTCGAGAAC } \\
\text { R: ACGAAGCCGTATGCTAA }\end{array}$ & $(\mathrm{CTTT})_{10}$ & 43 & 2 & $148-160$ & $\mathrm{PCR}_{\text {STD+HOT1 }}$ & - & - & - & - & KT730152 \\
\hline Mfsc11 & $\begin{array}{l}\text { F: GGAAGGACGAGAGAATTCAAGA } \\
\text { R: ATAGTCGTTTGTCGCGAGTGTA }\end{array}$ & $(\mathrm{CTTT})_{10}$ & 50 & 5 & 170-186 & $\mathrm{PCR}_{\mathrm{STD}}$ & + & + & - & - & KT730153 \\
\hline Mfsc13 & $\begin{array}{l}\text { F: GCAGTAACGGTAGCAGTGGTG } \\
\text { R: ACTCCTTTCTCCTTCTCGGTCT }\end{array}$ & $(\mathrm{ACG})_{16}$ & 52 & 2 & 189-207 & $\mathrm{PCR}_{\text {STD }}$ & + & - & - & - & KT730154 \\
\hline Mfsc14 & $\begin{array}{l}\text { F: AGTTGCAGCGTTTGTGAAATC } \\
\text { R: GTGGGTTCGGAGATGTGTATAAG }\end{array}$ & $(\mathrm{AGT})_{17}$ & $47-57$ & 2 & 116-122 & $\mathrm{PCR}_{\mathrm{TCD}+\text { HоT1 }}$ & + & - & - & - & KT730155 \\
\hline Mfsc17 & $\begin{array}{l}\text { F: ATTTTCTCAGTAAGCGAGTCCG } \\
\text { R: CGACCTTGTTCGTATAATAGCA }\end{array}$ & $(\mathrm{ATT})_{17}$ & 50 & 10 & $142-187$ & $\mathrm{PCR}_{\mathrm{STD}+\mathrm{HOT} 1}$ & - & - & - & - & KT730156 \\
\hline Mfsc22 & $\begin{array}{l}\text { F: GTGACAATAATAGGAGGGAAATCG } \\
\text { R: GAAGCTGGTACAGGTATCGGAG }\end{array}$ & $(\mathrm{GAT})_{14}$ & $58-48$ & 2 & $231-234$ & $\mathrm{PCR}_{\mathrm{TCD}+\mathrm{HOT} 1}$ & + & + & + & + & KT730157 \\
\hline Mfsc23 & $\begin{array}{c}\text { F: ATTCGGCATCGGCGTTAT } \\
\text { R: TTAGAGAAAGTTGTTGGACCCG }\end{array}$ & $(\mathrm{CGT})_{14}$ & 48 & 3 & $243-261$ & $\mathrm{PCR}_{\mathrm{STD}}$ & + & - & - & - & KT730158 \\
\hline Mfsc24 & $\begin{array}{c}\text { F: GTAGAGGAGTAGTAACAGCAA } \\
\text { R: CGAGTCCCGGTTAGC }\end{array}$ & $(\mathrm{AGC})_{14}$ & 48 & 4 & 165-189 & $\mathrm{PCR}_{\mathrm{STD}}$ & + & + & + & + & KT730159 \\
\hline Mfsc27 & $\begin{array}{l}\text { F: CGTCTCCACCGTCTTCTATTTC } \\
\text { R: GCGTGTCCTCTCTTTCTCTCTC }\end{array}$ & $(A G C)_{13}$ & 50 & 6 & $205-227$ & $\mathrm{PCR}_{\mathrm{STD}}$ & + & + & - & - & KT730160 \\
\hline Mfsc28 & $\begin{array}{l}\text { F: ATGATTCTCGCTTTCGTCGT } \\
\text { R: GTGAGGAGACGCTGGATTTC }\end{array}$ & $(A G C)_{13}$ & $52-62$ & 5 & 160-184 & $\mathrm{PCR}_{\mathrm{TCD}+\mathrm{HOT} 2}$ & + & + & - & + & KT730161 \\
\hline Mfsc30 & $\begin{array}{c}\text { F: TCTATAAGCGCCAGAGAGGAAG } \\
\text { R: TTTCAGGGATGCGCC }\end{array}$ & $(\mathrm{ACG})_{12}$ & 50 & 3 & 186-192 & $\mathrm{PCR}_{\text {STD }}$ & + & + & - & - & KT730162 \\
\hline Mfsc31 & $\begin{array}{l}\text { F: TGTGGTCGCGGTTGC } \\
\text { R: TCGCCGCTCGGAACT }\end{array}$ & $(\mathrm{AAG})_{12}$ & 50 & 2 & $260-263$ & $\mathrm{PCR}_{\text {STD }}$ & - & - & - & - & KT730163 \\
\hline Mfsc32 & $\begin{array}{l}\text { F: GTTATCGTTATCGTCATCGTCGT } \\
\text { R: CCGTGAGCGAACTCGAAC }\end{array}$ & $(\mathrm{CGT})_{12}$ & $47-57$ & 3 & $105-108$ & $\mathrm{PCR}_{\mathrm{TCD}+\mathrm{HOT} 1}$ & - & - & - & - & KT730164 \\
\hline Mfsc34 & $\begin{array}{c}\text { F: AACTTTGAGGACGCACGAG } \\
\text { R: CACTTCTTGTTCGACTTGGTTG }\end{array}$ & $(\mathrm{ACGA})_{12}$ & 53 & 1 & 109 & $\mathrm{PCR}_{\mathrm{STD}+\mathrm{HOT} 1}$ & - & - & - & - & KT730165 \\
\hline Mfsc36 & $\begin{array}{l}\text { F: CGCCTACACCTAGAACCAAAA } \\
\text { R: ACGTACACCGATGGCGTT }\end{array}$ & $(\mathrm{AAAG})_{13}$ & 55 & 9 & 097-109 & $\mathrm{PCR}_{\text {STD }}$ & - & - & - & - & KT730166 \\
\hline Mfsc37 & $\begin{array}{l}\text { F: GAAGGAAGGAAAGAGGCCG } \\
\text { R: CCATTGCTACCCGTACCTCC }\end{array}$ & $(\mathrm{AAAG})_{10}$ & 55 & 8 & 103-119 & $\mathrm{PCR}_{\text {STD }}$ & - & - & - & - & KT730167 \\
\hline
\end{tabular}

Ta - annealing temperature; $\mathrm{Na}$ - number of alleles; $\mathrm{PCR}_{\mathrm{STD}}-$ standard PCR $\left[94^{\circ} \mathrm{C}-1 \mathrm{~min} ; 40 \mathrm{cycles}\left(94^{\circ} \mathrm{C}-30 \mathrm{~s} ; \mathrm{Ta}-30 \mathrm{~s} ; 72^{\circ} \mathrm{C}-30 \mathrm{~s}\right) ; 72^{\circ} \mathrm{C}-3 \mathrm{~min}\right]$; $\mathrm{PCR}_{\mathrm{TCD}+\mathrm{Hor1}}$ : Touchdown PCR with HotStart Taq DNA polymerase $\left\{95^{\circ} \mathrm{C}-15 \mathrm{~min} ; 10\right.$ cycles $\left[94^{\circ} \mathrm{C}-30 \mathrm{~s} ; \mathrm{Ta}_{1}-30 \mathrm{~s} ; 72^{\circ} \mathrm{C}-30 \mathrm{~s}\right] ; 10 \mathrm{cycles}\left[94^{\circ} \mathrm{C}-30 \mathrm{~s}\right.$; $\mathrm{Ta}_{2}\left(-1^{\circ} \mathrm{C} /\right.$ cycles $\left.)-30 \mathrm{~s} ; 72^{\circ} \mathrm{C}-30 \mathrm{~s}\right] ; 25$ cycles $\left[94^{\circ} \mathrm{C}-30 \mathrm{~s} ; \mathrm{Ta}_{1}-30 \mathrm{~s} ; 72^{\circ} \mathrm{C}-30 \mathrm{~s}\right) ; 72^{\circ}-10$ min]\}; PCR ${ }_{\text {TCD }+ \text { Hot }}$ : Touchdown PCR with HotStart Taq DNA polymerase $=\left\{95^{\circ} \mathrm{C}-15 \mathrm{~min} ; 10\right.$ cycles $\left[94^{\circ} \mathrm{C}-30 \mathrm{~s} ; \mathrm{Ta}_{1}\left(-1,0^{\circ} \mathrm{C} / \mathrm{cycle}\right)-30 \mathrm{~s} ; 72^{\circ} \mathrm{C}-30 \mathrm{~s}\right] ; 25 \mathrm{cycles}\left[94^{\circ} \mathrm{C}-30 \mathrm{~s} ; \mathrm{Ta}^{\circ}-30 \mathrm{~s} ; 72^{\circ} \mathrm{C}-30 \mathrm{~s}\right] ; 72^{\circ} \mathrm{C}-10 \mathrm{~min}$.

ver.1.12 (Jakobsson \& Rosenberg, 2007) was used to align the five repetitions of the best $K$. The program Distruct ver. 1.1 (Noah, 2004) was used to graphically display the results produced by Clumpp. Population structure was also analyzed using principal coordinate analysis (PCoA), $R_{S T}$, a measure of genetic differentiation analogous to $F_{S T}$ but incorporating allele size information, and the $D_{e s t}$ estimator of actual differentiation as implemented in Genalex v. 6.5 (Peakall \& Smouse, 2012).

\section{RESULTS AND DISCUSSION}

\section{Sequence assembly, SSR identification and primer design}

The genomic library, which was previously loaded as $16 \%$ of a MiSeq Reagent Kit v2 300 cycle sequencing run, produced 2,669,884 reads, which were assembled into 47,087 contigs. The program msatcommander 0.8.2 (Faircloth, 2008) identified 9,954 contigs $(11.3 \%$ of total contigs) containing 11,869 microsatellite loci, being in the majority mononucleotide $(6,444)$ and dinucleotide $(3,225)$ repeats. For ease of imaging and scoring, we chose to examine only tri- (734) and tetranucleotide (574) loci. From these, 37 loci were chosen for primer designing and validation in $M$. fasciculata, based on the presence of long, uninterrupted repeat units ( $\geq 10$ repeats), flanking regions of at least $50 \mathrm{bp}$ in length containing no more than four monobase repeats $\left[(\mathrm{A})_{n},(\mathrm{G})_{n},(\mathrm{C})_{n},(\mathrm{~T})_{n}\right]$, and amplicon length between 100 and $270 \mathrm{bp}$.

\section{Polymorphism and validation of Melipona fasciculata SSR markers}

The Micro-Checker analysis of the entire dataset revealed null alleles for loci $M f s c 3$ and $M f s c 11$, at lower frequencies than 0.2 (Table 2). Null allele frequencies below 0.2 are acceptable in most microsatellite data sets (Dakin \& Avise, 2004). When the dataset was divided into two populations (Piauí and Maranhão) only locus $M f s c 3$ indicated the presence of nulls, which may be a possible cause of its deviation from $H W E$ in the Piauí population, even after Bonferroni correction for multiple comparisons at the 5\% significance level (critical value for $P>0.0029$ ). No loci showed significant linkage disequilibrium after Bonferroni correction.

PCR products of expected size with clear and consistent bands were obtained from 18 primer pairs, out of 37 sets tested on 50 individual bees from the two surveyed populations in Northeastern Brazil (Table 2). The proportion of markers that generated consistent amplicons within their expected sizes was $48.6 \%$. Expected product sizes for each microsatellite locus were based on sequence data from the partial genome assembly process. Seventeen microsatellite loci were polymorphic across the entire 
Table 2. Variability of 17 microsatellite loci and genetic diversity estimates in Melipona fasciculata.

\begin{tabular}{|c|c|c|c|c|c|c|c|c|c|c|c|c|c|c|c|c|c|c|c|c|c|}
\hline \multirow{2}{*}{ Locus } & \multicolumn{6}{|c|}{ All individuals $(n=50)$} & \multicolumn{6}{|c|}{ Piauí $(n=25)$} & \multicolumn{6}{|c|}{ Maranhão $(n=25)$} & \multirow{2}{*}{$F_{S T}$} & \multirow{2}{*}{$R_{\text {ST }}$} & \multirow{2}{*}{$D_{\text {est }}$} \\
\hline & $A_{R}$ & $H_{\mathrm{O}}$ & $H_{E}$ & PIC & $\mathrm{pHWE}$ & Nulli & $A_{\mathrm{R}}$ & $H_{0}$ & $H_{E}$ & $P I C$ & $\mathrm{pHWE}$ & Null & $A_{R}$ & $H_{0}$ & $H_{E}$ & $P I C$ & $\mathrm{pHWE}$ & Null & & & \\
\hline Mfsc3 & 2.0 & 0.000 & 0.186 & 0.167 & $0.000^{*}$ & 0.156 & 2 & 0.000 & 0.423 & 0.325 & $0.000^{*}$ & 0.290 & 1 & 0.000 & 0.000 & 0.000 & Mono & 0.000 & 0.321 & 0.424 & 0.089 \\
\hline Mfsc7 & 2.0 & 0.353 & 0.295 & 0.248 & 0.556 & -0.048 & 2 & 0.522 & 0.394 & 0.311 & 0.267 & -0.098 & 1 & 0.000 & 0.000 & 0.000 & Mono & 0.000 & 0.189 & 0.396 & 0.079 \\
\hline Mfsc10 & 2.0 & 0.617 & 0.431 & 0.336 & $0.002^{*}$ & -0.133 & 2 & 0.500 & 0.384 & 0.305 & 0.272 & -0.091 & 2 & 0.720 & 0.470 & 0.355 & 0.008 & -0.177 & 0.016 & 0.067 & 0.012 \\
\hline Mfsc11 & 4.9 & 0.326 & 0.646 & 0.570 & $0.000^{*}$ & 0.191 & 2 & 0.381 & 0.316 & 0.261 & 1.000 & -0.056 & 4 & 0.280 & 0.409 & 0.376 & 0.01 & 0.086 & 0.601 & 0.158 & 0.873 \\
\hline Mfsc13 & 2.0 & 0.306 & 0.262 & 0.226 & 0.575 & -0.037 & 2 & 0.625 & 0.439 & 0.337 & 0.055 & -0.137 & 1 & 0.000 & 0.000 & 0.000 & Mono & 0.000 & 0.309 & 0.084 & 0.122 \\
\hline Mfsc14 & 2.0 & 0.378 & 0.504 & 0.373 & 0.184 & 0.079 & 2 & 0.357 & 0.516 & 0.374 & 0.318 & 0.094 & 2 & 0.391 & 0.507 & 0.730 & 0.403 & 0.070 & -0.038 & $0.258-$ & -0.039 \\
\hline Mfsc17 & 9.1 & 0.732 & 0.610 & 0.550 & 0.013 & -0.081 & 5 & 0.611 & 0.571 & 0.501 & 0.038 & -0.036 & 7 & 0.826 & 0.642 & 0.572 & 0.047 & -0.122 & 0.003 & 0.103 & 0.004 \\
\hline Mfsc22 & 2.0 & 1.000 & 0.505 & 0.375 & $0.000^{*}$ & -0.333 & 2 & 1.000 & 0.512 & 0.375 & $0.000^{*}$ & -0.333 & 2 & 1.000 & 0.510 & 0.375 & $0.000^{*}$ & & 0.000 & 0.083 & 0.000 \\
\hline Mfsc23 & 3.0 & 0.864 & 0.574 & 0.494 & $0.000^{*}$ & -0.189 & 3 & 0.762 & 0.547 & 0.469 & 0.056 & -0.149 & 2 & 0.957 & 0.510 & 0.375 & $0.000^{*}$ & -0.305 & $0.161-$ & -0.019 & 0.207 \\
\hline Mfsc24 & 3.9 & 0.370 & 0.335 & 0.304 & 0.395 & -0.029 & 1 & 0.000 & 0.000 & 0.000 & Mono & 0.000 & 4 & 0.680 & 0.528 & 0.457 & 0.281 & -0.107 & 0.253 & 0.094 & 0.132 \\
\hline Mfsc27 & 5.9 & 0.979 & 0.762 & 0.714 & $0.000^{*}$ & -0.129 & 3 & 1.000 & 0.532 & 0.406 & $0.000^{*}$ & -0.315 & 5 & 0.960 & 0.731 & 0.668 & 0.008 & -0.142 & 0.290 & 0.017 & 0.684 \\
\hline Mfsc28 & 4.8 & 0.732 & 0.556 & 0.509 & 0.142 & -0.118 & 2 & 0.375 & 0.315 & 0.258 & 1.000 & -0.054 & 4 & 0.960 & 0.626 & 0.546 & $0.000^{*}$ & -0.215 & 0.182 & 0.351 & 0.209 \\
\hline Mfsc30 & 2.9 & 0.156 & 0.186 & 0.173 & 0.017 & 0.024 & 1 & 0.000 & 0.000 & 0.000 & Mono & 0.000 & 3 & 0.292 & 0.324 & 0.286 & 0.031 & 0.019 & 0.125 & 0.035 & 0.030 \\
\hline Mfsc31 & 2.0 & 0.073 & 0.116 & 0.108 & 0.120 & 0.037 & 2 & 0.188 & 0.272 & 0.229 & 0.302 & 0.060 & 1 & 0.000 & 0.000 & 0.000 & Mono & 0.000 & 0.164 & 0.333 & 0.023 \\
\hline Mfsc32 & 2.9 & 0.362 & 0.334 & 0.288 & $0.004^{*}$ & -0.024 & 3 & 0.773 & 0.538 & 0.427 & $0.000^{*}$ & -0.162 & 1 & 0.000 & 0.000 & 0.000 & Mono & 0.000 & 0.399 & 0.062 & 0.226 \\
\hline Mfsc36 & 8.3 & 1.000 & 0.746 & 0.700 & $0.000^{*}$ & -0.151 & 3 & 1.000 & 0.613 & 0.516 & $0.000^{*}$ & -0.252 & 9 & 1.000 & 0.817 & 0.775 & $0.000^{*}$ & -0.111 & 0.051 & 0.209 & 0.137 \\
\hline Mfsc37 & 7.4 & 0.872 & 0.664 & 0.601 & $0.000^{*}$ & -0.130 & 2 & 0.727 & 0.474 & 0.356 & 0.017 & -0.181 & 8 & 1.000 & 0.783 & 0.734 & $0.000^{*}$ & -0.132 & 0.082 & 0.131 & 0.151 \\
\hline Mean & 3.9 & 0.536 & 0.453 & 0.396 & - & - & 2.3 & 0.519 & 0.403 & 0.321 & - & - & 3.4 & 0.533 & 0.403 & 0.367 & - & - & 0.194 & 0.230 & 0.162 \\
\hline
\end{tabular}
$P<0.0029$ ). "Negative null-allele frequencies are a software artefact and can be interpreted as zero.

data set. However, a few revealed a monomorphic banding pattern within a population ( $M f s c 24$ and $M f s c 30$ in Piauí and $M f s c 3$, $M f_{s c} 7, M f_{s c} 13, M f_{s c} 31$ and $M f_{s c} 32$ in Maranhão). Nevertheless, it is expected that these loci may become polymorphic once again when additional individuals are sampled.

Ten out of the 18 M. fasciculata-specific microsatellite markers tested were transferable to other stingless bees (M. marginata, M. subnitida, Nannotrigona testaceicornis, and Frieseomelitta varia). However, heterologous amplification proved more successful with closely related species, with 10 loci (out of 18 tested loci, i.e. 55.6\%) in M. marginata and 6 loci (33.3\%) in M. subnitida. Cross-species amplification tests showed lower success rate for Frieseomelitta varia $(22.2 \%)$ and Nannotrigona testaceicornis $(11.1 \%)$, presumably due to the larger evolutionary distance between the target and the source species (Barbara et al., 2007).

The genotyping of the entire dataset revealed 70 alleles, ranging from one, for locus $M f s c 34$ to 10, for locus $M f s c 17$, with an average of $3.9 \pm 2.7$ alleles per locus (Table 2). This result was of similar magnitude to that found in other species within the same genus such as M. rufiventris (Lopes et al., 2009), M. seminigra merrillae (Francini et al., 2009), M. interrupta manaosensis (Francini et al., 2010), M. mondury (Lopes et al., 2010) and $M$. yucatanica (May-Itzá et al., 2010). The size of alleles in the least polymorphic locus $\left(H_{E}\right.$ and $\left.P I C\right), M f s c 31$, ranged from 260 to $263 \mathrm{bp}$, while for the most polymorphic locus, $M f_{s c} 27$, alleles varied from 205 to 227. These two loci ( $M f s c 31$ and $M f s c 27)$ were composed of trinucleotide motifs. As shown in Table 2, the level of polymorphism of each locus was also evaluated by the allelic richness $\left(A_{R}\right)$ and the polymorphic information content (PIC). The values of allelic richness varied from 2 to 9.1 (average of $3.9 \pm 2.4$ ), while $P I C$ values ranged between 0.108 and 0.714 . Mean PIC $(0.372 \pm 0.198)$ characterizes all microsatellite loci as reasonably informative markers (Botstein et al., 1980). Overall mean observed and expected heterozygosity was estimated to be 0.536 and 0.453 , respectively. These estimates were higher when compared to most heterozygosities found for Melipona species, exception made for M. subnitida (Souza et al., 2015). It is noteworthy that low levels of heterozygosity are known to occur in social Hymenoptera compared to other insects (Graur, 1985). Nine microsatellite loci exhibited significant probabilities
$(P<0.05)$ of departure from Hardy-Weinberg equilibrium, likely due to the mixing of individuals from populations of different allelic frequencies (Templeton, 2006). However, when populations were considered separately, the number of loci that deviated significantly from $H W E$ were five in each population (Table 2 ), mostly caused by excess of heterozygotes. $F_{I S}$ estimates for most loci were negative, also indicating a trend towards an excess of observed heterozygosity. In a population this feature could be a signature of population bottleneck events (Cornuet \& Luikart, 1996), which might be associated to destruction of native vegetation and consequent landscape transformation by human activities (Winfree et al., 2009; Potts et al., 2010).

\section{Assessment of the genetic diversity in Melipona fasciculata}

Genetic diversity between $M$. fasciculata populations, as measured by the mean number of alleles per microsatellite locus, mean allelic richness, heterozygosity and PIC, was characterized by a slightly higher level of genetic variability from samples collected in Maranhão when compared to those sampled in Piauí (Table 2).

The high $F_{S T}(0.194)$ and $R_{S T}(0.230)$ estimates found in $M$. fasciculata suggest the existence of genetic differentiation. However, additional genetic surveys should be carried out to confirm this observation. Similarly high $F_{S T}$ estimates were reported in wild populations of $M$. rufiventris (Tavares et al., 2007) and $M$. beecheii (Quezada-Euan et al., 2007), with values of 0.250 and 0.280 , respectively. $D_{e s t}$, which is a measure based on the proportion of alleles that are unique to a subpopulation, provided further evidence of population differentiation $\left(D_{\text {est }}=0.162\right)$. Low rates of dispersion and short flight distance, less than $2000 \mathrm{~m}$, might have contributed to the levels of population differentiation (Silveira et al., 2002; Araújo et al., 2004; Duarte et al., 2014).

The scatter-plot of the principal coordinates analysis ( $\mathrm{PCoA})$ showed a clear separation of the species in two distinct clusters of stingless bees ultimately defined by the origin of each individual population, therefore, confirming a significant molecular genetic difference between the two populations (Fig. 1A). The analysis of microsatellite variation using the admixture model of STRUCTURE, at the first level of sub-population separation $(K=2)$, have also revealed two distinct clusters (Fig. 1B). These clusters rep- 


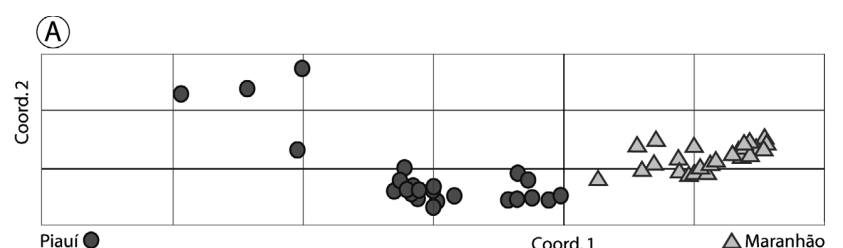

(B)

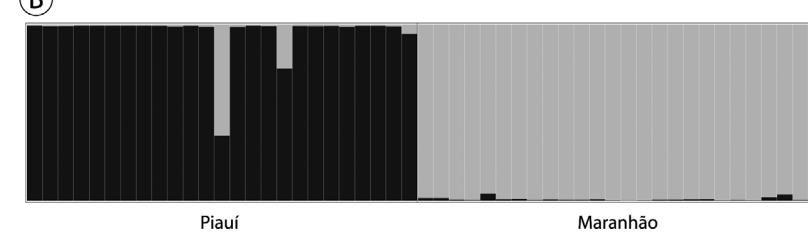

Fig. 1. A - Principal coordinates analysis of microsatellite variation in the stingless bee Melipona fasciculata; B - Genetic structure inferred using Bayesian analysis in the program STRUCTURE. Each individual is represented by a vertical bar.

resent each sampling population separately, except for very few individuals mostly located in Piauí that appears to be admixed.

All these estimates indicate that there is little contemporary gene flow between these two M. fasciculata populations. This suggests questions about whether the destruction of native semiarid vegetation is increasing genetic drift by reducing genetic connectivity among $M$. fasciculata populations currently restricted to the remaining fragments of native forests.

Overall, analyses provide provisional evidence of significant population differentiation between Maranhão and Piauí, in $M$. fasciculata. However, the data generated by this study should be further investigated using the same microsatellites markers, but larger sample size and more widespread sampling throughout the distribution of the species. Given all these considerations, the 18 isolated microsatellite loci have demonstrated strong potential for population-level genetic studies and can be used effectively as molecular tools to aid in the conservation of the species. Crossspecies amplification further indicates that most of these loci can be useful across a wider range of species. Moreover, the results obtained from this snapshot assessment of the genetic diversity in M. fasciculata support their use for conducting population genetics and landscape genetics studies.

ACKNOWLEDGEMENTS. Embrapa (The Brazilian Agricultural Research Corporation) funded this study through the project grant no. MP 06.14.01.001.00.00. This study was also financed in part by the Coordenação de Aperfeiçoamento de Pessoal de Nível Superior - Brasil (CAPES). Sequencing was conducted on a MiSeq DNA sequencer purchased with a bequest from E.A. Nielsen to the Marine Gene Probe Laboratory. The authors are grateful to J.M. Vieira-Neto (in memoriam) for help in field collection. We also thank two anonymous reviewers for comments that considerably improved the manuscript.

\section{REFERENCES}

Alves R.M.O. 2013: Production and marketing of pot-honey. In Vit P., Pedro S.R.M. \& Roubik D.W. (eds): Pot-Honey: A Legacy of Stingless Bees. Springer, New York, pp. 541-556.

Araújo E.D., Costa M., Chaud-Netto J. \& Fowler H.G. 2004: Body size and flight distance in stingless bees (Hymenoptera: Meliponini): inference of flight range and possible ecological implications. - Braz. J. Biol. 64: 563-568.

Barbara T., Palma-Silva C., Paggi G.M., Bered F., Fay M.F. \& LEXER C. 2007: Cross-species transfer of nuclear microsatel- lite markers: potential and limitations. — Mol. Ecol. 16: 3759 3767.

Botstein D., White R.L. \& Skolnick M. 1980: Construction of a genetic linkage map in man using restriction fragment length polymorphisms. - Am. J. Hum. Genet. 32: 314-331

Byatt M.A., Chapman N.C., LatTy T. \& Oldroyd B.P. 2016: The genetic consequences of the anthropogenic movement of social bees. - Insectes Soc. 63: 15-24.

CoRnuet J.M. \& LuiKart G. 1996: Description and power analysis of two tests for detecting recent population bottlenecks from allele frequency data. - Genetics 144: 2001-2014.

DAKIn E.E. \& Avise J.C. 2004: Microsatellite null alleles in parentage analysis. - Heredity 93: 504-509.

Duarte O.M.P., Gaiotto F.A. \& Costa M.A. 2014: Genetic differentiation in the stingless bee, Scaptotrigona xanthotricha Moure, 1950 (Apidae, Meliponini): a species with wide geographic distribution in the Atlantic rainforest. $-J$. Hered. 105: 477-484.

Dutra R.P., Abreu B.V.B., Cunha M.S., Batista M.C.A., Torres L.M.B., NAscimento F.R.F., Ribeiro M.N.S. \& Guerra R.N.M. 2014: Phenolic acids, hydrolyzable tannins, and antioxidant activity of geopropolis from the stingless bee Melipona fasciculata Smith. - J. Agri. Food Chem. 62: 2549-2557.

EARL D.A. \& VonHoldt B.M. 2012: STRUCTURE HARVESTER: a website and program for visualizing STRUCTURE output and implementing the Evanno method. - Conserv. Genet. Resour. 4: 359-361.

EXCOFfIER L. \& Lischer H.E.L. 2010: Arlequin suite v 35: a new series of programs to perform population genetic analysis under Linux and Windows. - Mol. Ecol. Res. 10: 564-567

FAIRCLOTH B. 2008: Msatcommander: detection of microsatellite repeat arrays and automated, locus-specific primer design. Mol. Ecol. Res. 8: 92-94.

Francini I.B., Sforça D.A., Sousa A.C.B., Campos T., Cidade F.W., Zucchi M.I., Souza A.P., Nunes-Silva C.G. \& CarvalhoZILSE G.A. 2009: Microsatellite loci for an endemic stingless bee Melipona seminigra merrillae (Apidae, Meliponini) from Amazon. - Conserv. Genet. Resour. 1: 487-490.

Francini I.B., Sousa A.C.B., Sforça D.A., Costa-Pinto M.F.F., Campos T., Nunes-Silva C.G., Zucchi M.I., Souza A.P. \& Carvalho-Zilse G.A. 2010: Isolation and characterization of microsatellite loci in the stingless bee Melipona interrupta manaosensis (Apidae: Meliponini). — Conserv. Genet. Resour. 2: $27-30$.

Garibaldi L.A., Steffan-Dewenter I., Winfree R., Aizen M.A., Bommarco R. \& CunNingham S.A. 2013: Wild pollinators enhance fruit set of crops regardless of honeybee abundance. Science 339: 1608-1611.

Goldstein D.B. \& SchlötTerer C. 1999: Microsatellites: Evolution and Applications. Oxford University Press, Oxford, 352 pp.

GosTINSKI L.F. 2018: Recursos alimentares e forrageamento de duas espécies de abelhas sem ferrão - Melipona (Melikerria) fasciculata Smith, 1854 e Melipona flavolineata Friese, 1900 (Apidae, Meliponini) - na região da Baixada Maranhense. $\mathrm{PhD}$ thesis, Universidade Federal do Maranhão, São Luís, 130 pp.

GOUDET J. 1995: FSTAT Version 2932: a computer program to calculate F-statistics. - J. Hered. 86: 485-486.

GRAUR D. 1985: Gene diversity in Hymenoptera. - Evolution 39: 190-199.

Holanda C.A., Oliveira A.R., Costa M.C.P., Ribeiro M.N.S., SouzA J.L. \& ARAúJo M.J.A.M. 2012: Qualidade dos méis produzidos por Melipona fasciculata Smith da região do cerrado maranhense. - Quím. Nova 35: 55-58. 
Jaffé R., Pope N., Carvalho A.T., Maia U.M., Blochtein B., Carvalho C.A.L. \& Imperatriz-Fonseca V.L. 2015: Bees for development: Brazilian survey reveals how to optimize stingless beekeeping. - PLOS ONE 10(3): e0121157, 21 pp.

Jaffé R., Pope N., Acosta A.L., Alves D.A., Arias M.C., De la Rúa P., Francisco F.O., Giannini T.C., GonzÁlez-Chaves A., Imperatriz-Fonseca V.L., TAVARES M.G., Jha S. \& CARVALheiro L.G. 2016: Beekeeping practices and geographic distance, not land use, drive gene flow across tropical bees. - Mol. Ecol. 25: $5345-5358$.

JAKOBSSON M. \& Rosenberg N.A. 2007: CLUMPP: a cluster matching and permutation program for dealing with label switching and multimodality in analysis of population structure. - Bioinformatics 23: 1801-1806.

Kalinowski S.T., Taper M.L. \& Marshal T.C. 2007: Revising how the computer program CERVUS accommodates genotyping error increases success in paternity assignment. - Mol. Ecol. 16: 1099-1106.

Kerr W.E., Carvalho G.A. \& Nascimento V.A. 1996: Abelha uruçu: Biologia, manejo e conservação. Fundação Acangaú, Belo Horizonte, MG, 143 pp.

Klein A.-M., Vaissière B.E., Cane J.H., Steffan-Dewenter I., Cunningham S.A., Kremen C. \& TscharntKe T. 2007: Importance of pollinators in changing landscapes for world crops. - Proc. Biol. Sci. 274: 303-313.

Liberio S.A., Pereira A.L.A., Dutra R.P., Reis A.S., AraúJo M.J.A.M., MatTar N.S., Silva L.A., Ribeiro M.N.S., NasciMENTO F.R.F., GuerRa R.N.M. \& MonteIRo-NEto V. 2011: Antimicrobial activity against oral pathogens and immunomodulatory effects and toxicity of geopropolis produced by the stingless bee Melipona fasciculata Smith. - BMC Complement. Altern. Med. 11: 108, 10 pp.

Lopes D.M., Silva F.O., Salomão T.M.F., Campos L.A.O. \& TAVARes M.G. 2009: Microsatellite loci for the stingless bee Melipona rufiventris (Hymenoptera, Apidae). - Mol. Ecol. Res. 9: 923-925.

Lopes D.M., Silva F.O., Fernandes-Salomão T.M., Campos L.A.O. \& TAVARES M.G.A. 2010: Scientific note on the characterization of microsatellite loci for Melipona mondury (Hymenoptera: Apidae). - Apidologie 41: 138-140.

MaY-Itzá W.J., Quezada-Eú́N J.J.G., Medina L.A.M., EnRIQuez E. \& De LA RÚA P. 2010: Morphometric and genetic differentiation in isolated populations of the endangered Mesoamerican stingless bee Melipona yucatanica (Hymenoptera: Apoidea) suggest the existence of a two species complex. - Conserv. Genet. 11: 2079-2084.

NOAH A.R. 2004: Distruct: a program for the graphical display of population structure. - Mol. Ecol. Notes 4: 137-138.

Nogueira J., Ramos J.C., Benevenuto J., Fernandes-Salomão T.M., Resende H.C., Campos L.A.O. \& Tavares M.G. 2014: Conservation study of an endangered stingless bee (Melipona capixaba - Hymenoptera: Apidae) with restricted distribution in Brazil. - J. Insect Conserv. 18: 317-326.

Nunes-Silva P., Hrncir M., Silva C.I., Roldão Y.S.O. \& ImPeraTRIZ-FONSECA V.L. 2013: Stingless bees, Melipona fasciculata, as efficient pollinators of eggplant (Solanum melongena) in greenhouses. - Apidologie 44: 537-546.

Peakall R. \& Smouse P.E. 2012: GenAlEx 65: Genetic analysis in Excel population genetic software for teaching and research: An update. - Bioinformatics 28: 2537-2539.

Potts S.G., Biesmeijer J.C., Kremen C., Neumann P., Schweiger O. \& KUNIN W.E. 2010: Global pollinator declines: trends, impacts and drivers. - Trends Ecol. Evol. 25: 345-353.

Pritchard J.K., Stephens M. \& DonNelly P. 2000: Inference of population structure using multilocus genotype data. - Genetics 155: 945-959.
Quezada-EuÁn J.J.G., Paxton R.J., Palmer K.A., May-ItZa W.J., TAY W.T. \& OLdROYD B.P. 2007: Morphological and molecular characters reveal differentiation in a Neotropical social bee, Melipona beecheii (Apidae: Meliponini). — Apidologie 38: $1-12$.

RAYMOND M. \& Rousset F. 1995: An exact test for population differentiation. - Evolution 49: 1280-1283.

Rozen S. \& Skaletsky H.J. 2000: Primer 3 on the www for general users and for biologist programmers. In Krawetz S. \& Misener S. (eds): Bioinformatics Methods and Protocols: Methods in Molecular Biology. Human Press, Totowa, pp. 365-386.

Selkoe K.A. \& Toonen R.J. 2006: Microsatellites for ecologists: a practical guide to using and evaluating microsatellite markers. - Ecol. Lett. 9: 615-629.

Silva G.R., Pereira F.M., Souza B.A., Lopes M.T.R., Campelo J.E.G. \& Diniz F.M. 2014: Bioecological and behavioral genetic aspects involved in the conservation of the stingless bee Melipona subnitida Ducke (Apidae, Meliponini) and the use of molecular tools in studies of diversity. - Arq. Inst. Biol. 81: 299-308.

Silva I.P., Oliveira F.A.S., Pedroza H.P., Gadelha I.C.N., Melo M.M. \& Soto-Blanco B. 2015: Pesticide exposure of honeybees (Apis mellifera) pollinating melon crops. - Apidologie 46: 703-715.

Silveira F.A., Melo G.A.R. \& Almeida E.A.B. 2002: Abelhas do Brasil: Sistemática e Identificação, 1st ed. Author's edition Belo Horizonte, 253 pp.

Souza I.G.B., Paterson I., Mcbride M.C., Souza B.A., Pereira F.M., Lopes M.T.R., Bentzen P. \& Diniz F.M. 2015: Isolation and characterization of 23 microsatellite loci in the stingless bee Melipona subnitida using next-generation sequencing. Conserv. Genet. Resour. 7: 239-241.

Tavares M.G., Dias L.A.S., Borges A.A., Lopes D.M., Busse A.H.P., Costa R.G., Fernandes-Salomão T.M. \& Campos L.A.O. 2007: Genetics divergence between populations of the stingless bee uruçu-amarela (Melipona rufiventris group, Hymenoptera, Meliponini): Is there a new Melipona species in the Brazilian state of Minas Gerais? - Gen. Mol. Biol. 30: 667-675.

Templeton A.R. 2006: Population Genetics and Microevolutionary Theory. John Wiley, Hoboken, NJ, 705 pp.

Van Oosterhout C., Hutchinson W.F., Wills D.P.M. \& Shipley P. 2004: Micro-Checker: software for identifying and correcting genotyping errors in microsatellite data. - Mol. Ecol. Notes 4: 535-538.

Venturieri G.C., Alves D.A., Villas-Bôas J.K., Carvalho C.A.L., Menezes C., Vollet-Neto A. \& Imperatriz-Fonseca V.L. 2012: Meliponicultura no Brasil: situação atual e perspectivas futuras para o uso na polinização agrícola. In ImperatrizFonseca V.L., Canhos D.A.C., Alves D.A. \& Saraiva A.M. (eds): Polinizadores no Brasil - contribuição e perspectivas para a biodiversidade, uso sustentável, conservação e serviços ambientais. EDUSP, São Paulo, pp. 213-236.

Winfree R., Aguilar R., Vazquez D.P., Lebuhn G. \& Aizen M.A. 2009: A meta-analysis of bees' responses to anthropogenic disturbance. - Ecology 90: 2068-2076.

Zalapa J.E., Cuevas H., Zhu H., Steffan S., Senalik D., Zeldin E., Mccown B., Harbut R. \& Simon P. 2012: Using next-generation sequencing approaches to isolate simple sequence repeat (SSR) loci in the plant sciences. - Am. J. Bot. 99: 193-208.

Received July 12, 2018; revised and accepted October 3, 2018 Published online October 24, 2018 